核融合研究第 49 巻第 6 号 1983 年 6 月

強磁性体壁によるヘリカル磁場の

形成とプラズマの安定化

西村清彦, 小森彰夫, 小出芳彦, 佐藤徳芳

( 東北大学工学部)

（1983 年 4 月 14 日受理）

\title{
Formation of Helical Magnetic Configuration by the \\ Use of Ferromagnetic Material
}

\author{
Kiyohiko Nishimura, Akio Komori \\ Yoshihiko Koide, Noriyoshi Sato
}

(Received April 14, 1983)

\begin{abstract}
An attempt is carried out to form an $\ell=3$ straight helical configuration of magnetic field using a shaped ferromagnetic material in a uniform magnetic field. The realized field has a feature expected for the $\ell=3$ field, and the rotationaltransform angle and shear length agree with predicted values within a factor of three. This $\ell=3$ helical magnetic field is used to stabilize drift-wave instability in a collisionless plasma.
\end{abstract}

序論

磁場中に強磁性体を置くと強磁性体は磁化されて, もとの磁場が変形されるてとは良く知られてい る。一般に, この性質は閉じ込め磁場を乱すものとして嫌われており, 装置の近くに強磁性体を置く ことは避けられている。しかし，ての性質をうまく利用するととによりプラズマの安定化や 1）一様 磁場の変形に強磁性体を利用するととができる。しかも, 多段えラー磁場を作る場合には, 電流では 作るととができない程にセル長の短い磁場配位を作るととができるという利点がある ${ }^{2)}$, また, 電流 が不要であるために, 装置のモジュール化が容易であるという工学上の利点もある。

最近, 強磁性体を用いてヘリカル磁場配位を形成する装置が生田ら ${ }^{3 ）}$ にっって提案された。ての 様な複雑な磁場配位を，強磁性体を用いて形成できれば，強磁性体の用途をさらに広げるてとがでさる。

Department of Electronic Engineering, Tohoku University, Sendai, Japan 
西村, 小森, 小出, 佐藤

そてで我々は生田らの考光をもとに強磁性体を用いたへリカル磁場を，実験的に形成するてとを試み k。

ヘリカル磁場配位を持つ装置としては，ステラレータ ${ }^{4)}$ やリオトロン ${ }^{5)}$ ，トルサトロン 6）が掲 げられる。てれらはトカマクの様にトロイダル電流を流すととなしに、シャ一磁場配位を得るととが でき,プラズマの安定を保つととが可能である。てのため炻として定常運転が可能な装置として, 最 近研究が盛んである。しかしながら, ヘリカル巻線の設計や組み立てには高い精度が必要であるため, トーラスの主軸を完全に囲む様に巻かれる構造では, 組み立てや補修のための分解には多くの時間と 労力, それに困難を伴なう。しかし, 強磁性体を用いるとへリカル 巻線が不要となり, 装置のモジュ ール化ができて，てれらの欠点を解決するてとができる。

“強磁性体を用いて核融合炬が実現でさるかという問題は最初にS heffield によって検討された1)。 彼の論文では, $\ell=3$ の場合, 1.0 テスラ程度までの閉じ込め磁場を持つ装置しか実現できないとされ ている。しかしながら, その後生田らにより $\ell=2$ の場合についての検討がなされ ${ }^{3)}$, 適当なパラメ 一タを選ぶととより, 強磁性体材料として汎用の軟鉄を用いても, 核融合炬として十分な回転変換 角を持つ装置を実現できると結論された。しかし，生田らの議論は理論的検討であり，本研究の結果 を用いるととにより,さらに現実的な検討が可能になると考えられる。

§ 1. では, ヘリカル磁場の形成方法と磁場のパラメータの計算方法について述べる。ミ2.では, 実際に形成されたシャ一磁場により不安定波が安定化されたてとについて述べる。

§1. ヘリカル強磁性体により作られる磁場

1-1 強磁性体により作られる磁場の基本的考え方

1-1-1 理想的なへリカル強磁性体により作られる磁場

ヘリカルな内壁をもつ円筒は図 1 々示した様な断面を持つ。こてでュ軸は円筒軸方向とし, 円筒は軸方向 に無限に長いと仮定する。これに十分大きな一様磁場 $\mathrm{B}_{0}$ を軸方向に印加した場合を考える。との時, 円筒の 内壁の山凸には $\mathrm{z}$ 軸に沿って正·負の磁荷 が現われ,ての凹凸が $\mathrm{z}$ 軸に対してヘリカル 対称性を持っているために, 磁荷も $\mathrm{z}$ 軸をら せん状にとりまく様に現われる。その結果 ヘリカル磁場が形成されると考朰れる。

いま一様磁場 $\mathrm{B}_{0}$ により磁化された強 磁性体内の磁化ベクトルを $\mathbf{M}$ ，その

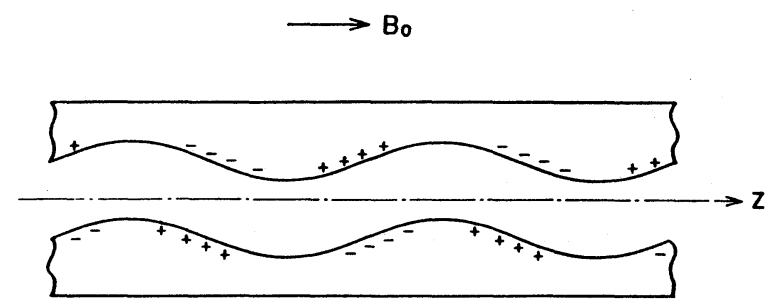

図 1．強磁性体に現われる磁荷 


\section{強磁性体壁によるへリカル磁場の形成とプラズマの安定化}

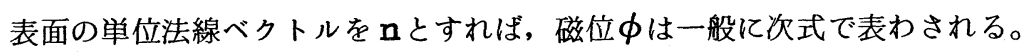

$$
\phi=-\mathrm{B}_{0} z+\frac{\mu_{0}}{4 \pi} \int \frac{\mathrm{n} \cdot \mathrm{M}}{\mathrm{R}} \mathrm{dS} \quad(1-1)
$$

ことでRは強磁性体表面から観測点までの距離であり， dS は面素である。強磁性体の内壁をヘリカ ル対称とすると, 円筒座標 $(\mathrm{r}, \theta, \mathrm{z})$ を用いて次式の様に表わされる。

$$
\mathrm{r}=\mathrm{r}_{0}\{1+\varepsilon \sin (\ell \theta-\mathrm{kz})\}
$$

こてで $\mathrm{r}_{0}$ は内壁の平均半径, $\varepsilon$ は内径の平均変化率, $\ell$ はへリカルのモード数, $\mathrm{k}$ は $\mathrm{z}$ 方向のヘリカ ルの波数を表わしている。

いま，磁化ベクトルが理想的に印加磁場と同方向を向いていると仮定する。

$$
M=M(0,0,1)
$$

この時, ( $1-1)$ 式は次の様に書ける。

$$
\phi=-\mathrm{B}_{0} z-\frac{\mu_{0} \mathrm{Mkr}_{0} \varepsilon}{4 \pi} \int_{0}^{2 \pi} \mathrm{d} \Theta \int_{-\infty}^{\infty} \frac{\mathrm{r}_{0} \cos (\ell \Theta-\mathrm{k} Z) \mathrm{d} Z}{\left[\mathrm{r}_{0}^{2}-2 \mathrm{r}_{0} \mathrm{r} \cos (\Theta-\theta)+\mathrm{r}^{2}+(Z-z)^{2}\right]^{1 / 2}}
$$

Zについての積分を実行すると

$$
\phi=-\mathrm{B}_{0} \mathrm{z}-\frac{\mu_{0} \mathrm{Mkr}_{0}^{2} \varepsilon}{2 \pi} \cos \beta \int_{0}^{2 \pi} \cos \ell \mathrm{t} \mathrm{K}_{0}\left(\mathrm{k} \sqrt{\mathrm{r}_{0}^{2}-2 \mathrm{r}_{0} \mathrm{r} \cos \mathrm{t}+\mathrm{r}^{2}}\right) \mathrm{dt}
$$

となる。但し, $\mathrm{t}=\oplus-\theta, \quad \beta=\ell \theta-\mathrm{kz}, \mathrm{K}_{0}$ は零次の第二種変形ベッセル関数である。 ( $1-5)$ 式はベッセル関数を用いて

$$
\phi=-\mathrm{B}_{0} z-\mu_{0} \mathrm{Mkr}_{0}^{2} \varepsilon \mathrm{K}_{\ell}\left(\mathrm{kr}_{0}\right) \mathrm{I}_{\ell}(\mathrm{kr}) \cos \beta
$$

と表わされる ${ }^{7)}$ 。 $\mathrm{I}_{\ell}, \mathrm{K}_{\ell}$ はそれぞれ $\ell$ 次の第一種及び第二種の変形ベッセル関数である。

$\mathbf{B}=-\nabla \phi よ り$, 磁場の各成分は次の様に書ける。

$$
\mathrm{B}_{\mathrm{r}}=\mu_{0} \mathrm{Mkr}_{0}^{2} \varepsilon \mathrm{K}_{\ell}\left(\mathrm{kr}_{0}\right) \frac{\partial \mathrm{I}_{\ell}(\mathrm{kr})}{\partial \mathrm{r}} \cos \beta
$$




$$
\begin{aligned}
& \mathrm{B}_{\theta}=-\frac{\ell}{\mathrm{r}} \mu_{0} \mathrm{Mkr}_{0}^{2} \varepsilon \mathrm{K}_{\ell}\left(\mathrm{kr}_{0}\right) \mathrm{I}_{\ell}(\mathrm{kr}) \sin \beta \\
& \mathrm{B}_{\mathrm{Z}}=\mathrm{B}_{0}+\mu_{0} \mathrm{Mk}^{2} \mathrm{r}_{0}^{2} \varepsilon \mathrm{K}_{\ell}\left(\mathrm{kr}_{0}\right) \mathrm{I}_{\ell}(\mathrm{kr}) \sin \beta
\end{aligned}
$$

また, 磁束関数 $\Psi$ は $(\nabla \Psi) \cdot \mathbf{B}=0$ の関係より

$$
\Psi=\frac{\mathrm{B}_{0}}{2} \mathrm{kr}^{2}+\mu_{0} \mathrm{Mkr}_{0}^{2} \varepsilon \mathrm{K}_{\ell}\left(\mathrm{kr}_{0}\right) \mathrm{r} \frac{\partial \mathrm{I}_{\ell}(\mathrm{kr})}{\partial \mathrm{r}} \sin \beta \quad(1-8)
$$

となる。以上より，一周期当りの回転変換角 しは

$$
\frac{c}{2 \pi}\left(\frac{\mathrm{b}}{2 \mathrm{~B}_{0}}\right)^{2}\left(\frac{\mathrm{d}}{\rho \mathrm{d} \rho}\right)^{2} \mathrm{I}^{2} \ell(\ell \rho)
$$

で与えられる。但し, $\rho \equiv \mathrm{kr} / \ell, \mathrm{b}=\mu_{0} \mathrm{M} \varepsilon\left(\mathrm{kr}_{0}\right)^{2} \mathrm{~K}_{\ell}\left(\mathrm{kr}_{0}\right) / \ell$ である。

以上, $(1-6)$ 式 ( $1-9)$ 式で表わされる磁場のパラメータはヘリカル電流により得られる ものと, 空間依存性が全く同じである。このととは, 磁化べクトルMに対する仮定が正しければ， 、 リカル電流によって作られる磁場配位を強磁性体によっても作るととが可能であるととを示している。

こてで $\mu_{0} \mathrm{M}$ の值は, 印加磁場がある程度大きくなると飽和して, 材料に固有の值をとる。従って

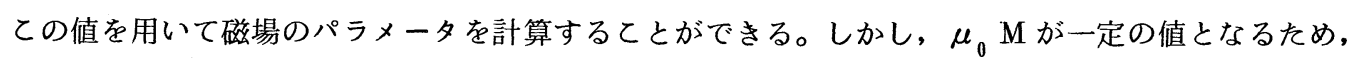
磁場のパラメータ, 例えば回転変換角を変化させるためには印加磁場 $\mathrm{B}_{0}$ を変化させなければならない。 てれが,ヘリカル電流の值を変えて磁場のパラメータを変えられる通常の磁場と異なる点である。 $\mu_{0} \mathrm{M}$ とへリカル電流 $\mathrm{I}_{\mathrm{H}}$ との対応は次式の様になる ${ }^{8)}$ 。

$$
\mu_{0} \mathrm{M}=\mathrm{I}_{\mathrm{H}} \frac{2 \mu_{0} \mathrm{~K}_{\ell}^{\prime}\left(\mathrm{kr}_{0}\right)}{\pi \mathrm{r}_{0} \varepsilon \mathrm{K}_{\ell}\left(\mathrm{kr}_{0}\right)}\left\{1+\left(\frac{\mathrm{kr}_{0}}{\ell}\right)^{2}\right\}^{-1 / 2}
$$

一般に軟鉄の飽和磁化の值は, $\mu_{0} \mathrm{M} \cong 15 \mathrm{kG}$ である。てれに対するヘリカル電流 $\mathrm{I}_{\mathrm{H}}$ の値は, $\mathrm{k}=0.69 \mathrm{rad} / \mathrm{cm}, \mathrm{r}_{0}=4.1 \mathrm{~cm}, \ell=3, \varepsilon=0.1, \mathrm{~B}_{0}=2 \mathrm{kG}$ で $\mathrm{I}_{\mathrm{H}} \cong 6.8 \mathrm{kA}$ となる。ま た, $\mathrm{k}=0.69 \mathrm{rad} / \mathrm{cm}, \mathrm{r}_{0}=6.5 \mathrm{~cm}, \ell=3, \mathrm{~L}($ プラズマ長 $)=3.4 \mathrm{~m}, \varepsilon=0.1, \mathrm{~B}_{0}=$ $4 \mathrm{kG}$ とすれば し/ $2 \pi \cong 1$ となり,ステラレータ装置 J I P P - Ib で得られるのとほぼ等しい回 転変換角が得られる。 
1-1-2 不連続に変化する強磁性体壁によるヘリカル磁場の形成

実際装置を作る場合，（1－2）式で表わされる様な滑らかな内壁を実現するととは難しいが, 図2で示される様に軟鉄円板に三角形の穴をくり六たもの（鉄リング）を $\mathrm{z}$ 軸に沿って少しずつ回 転せながら密着して並べるてとにより,近似的なへリカル強磁性体壁を実現できる。ての時, 鉄リング 表面に現われる磁荷は図 3 , 汹4 の様になると考えられ，てれが滑らかな壁に現われる磁荷と等価な 働きをするてとを以下の様にして確かめた。

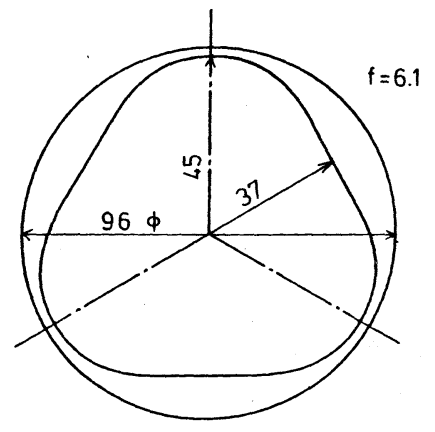

図 2.鉄リング

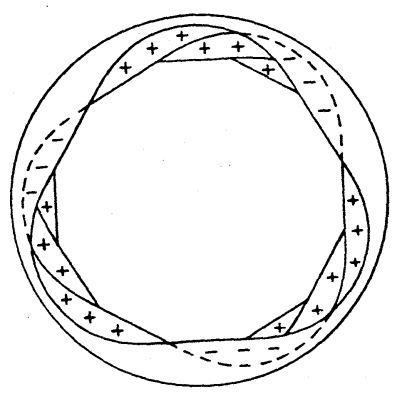

図 3.鉄リングに現われる磁荷

まず，磁位の計算を行なった。磁位は，鉄 リングー枚ずつに対しての磁位を求め, 各々 の和をとるととにより計算される。また，磁 場は $\mathbf{B}=-\nabla \boldsymbol{\phi}$ より求められる。

一枚のリングによる磁位を $\phi_{i}$ とすると

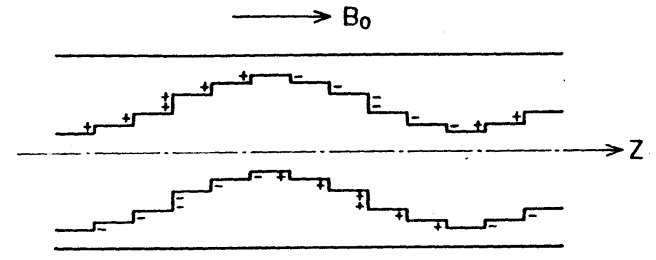

図 4. 強磁性体壁断面

$$
\begin{aligned}
& \phi_{\mathrm{i}}=-\frac{\mu_{0} \mathrm{M}}{4 \pi} \int_{\mathrm{r}_{\mathrm{S}}}^{\mathrm{r}_{\mathrm{L}}} \mathrm{RdR} \int_{0}^{2 \pi} \mathrm{d} \Theta \\
& \times\left[\frac{1}{\left\{\mathrm{R}^{2}+\mathrm{r}^{2}-2 \mathrm{Rr} \cos (\theta-\theta)+\left(\mathrm{Z}_{\mathrm{i}}+\mathrm{w}-\mathrm{z}\right)^{2}\right\} \quad 1 / 2}\right. \\
& \left.-\frac{1}{\left\{R^{2}+r^{2}-2 R r \cos (\theta-\theta)+\left(Z_{i}-w-z\right)^{2}\right\}^{1 / 2}}\right](1-11)
\end{aligned}
$$


となる。こてで $\mathrm{Z}_{\mathrm{i}}$ は鉄リング中央の $\mathrm{z}$ 座標, $2 \mathrm{w}$ は鉄リングの厚さ $(\mathrm{t}=2 \mathrm{w}), \mathrm{r}_{\mathrm{L}}$ は外半径, $\mathrm{r}_{\mathrm{s}}=\mathrm{r}_{0}\left\{1+\varepsilon \sin \left(\ell \circledast-\mathrm{k} \mathrm{Z}_{\mathrm{i}}\right)\right\},\left(\mathrm{R}, \Theta, \mathrm{Z}_{\mathrm{i}} \pm \mathrm{w}\right)$ は強磁性体表面の座標, $(\mathrm{r}, \boldsymbol{\theta}$, z ）は観測点の座標である。右辺第一項は $\mathrm{z}$ 軸方向を向いた面による磁位を表わし，右辺第二項は逆 方向を向いた面による磁位を表わしている。従って, 求める磁位中は各々のリングによる磁位 $\phi_{\mathrm{i}} に$, 印加磁場による磁位 $\phi_{0}=-\mathrm{B}_{0} \mathrm{z}$ を加えるととにより得られる。

$$
\phi=-\mathrm{B}_{0} z+\underset{\mathrm{i}}{\sum} \phi_{\mathrm{i}}
$$

この式は， $\mathrm{R} \cong \mathrm{r}_{0}, 2 \mathrm{w}=\Delta \mathrm{Z}, \mathrm{k} \Delta \mathrm{Z} \ll 1$ として円筒近似を用いると

$$
\begin{aligned}
\phi= & -\mathrm{B}_{0} \mathrm{z}-\frac{\mu_{0} \mathrm{Mk} \mathrm{r}_{0}^{2} \varepsilon}{4 \pi} \sum_{\mathrm{i}} \int_{0}^{2 \pi} \mathrm{d} \Theta \\
& \times\left[\frac{\Delta \mathrm{Z} \cos \left\{\ell \Theta-\mathrm{k}\left(\mathrm{Z}_{\mathrm{i}}+\mathrm{w}\right)\right\}}{\left\{\mathrm{r}_{0}^{2}+\mathrm{r}^{2}-2 \mathrm{r}_{0} \mathrm{r} \cos (\Theta-\theta)+\left(Z_{\mathrm{i}}+\mathrm{w}-\mathrm{z}\right)^{2}\right\}} 1 / 2\right]
\end{aligned}
$$

となる。これは $(1-4)$ 式と等価である。従って, ての方法でも滑らかな内壁による磁場配位と等 価なものが形成できるととがわかる。

\section{$1-1-3$ 隙間のある強磁性体円筒によるへリカル磁場の形成}

前節の方法では厚さ $61 \mathrm{~mm}$ の比較的薄い鉄リングを用いるために，多くの鉄リングが必要である。 そてで，ての節では厚みのある鉄リングを用いるととにより，少ないリングの数で前節の方法で得ら れるのとほぼ等しい回転変換角を得る方法を述べる。との方法を用いるととにより鉄リングの加工及 び組み立てが容易になる。

具体的な方法は，図 5 で示した様に，厚さDの鉄リングを $\mathrm{z}$ 軸に沿って少しづつ回転させながら隙
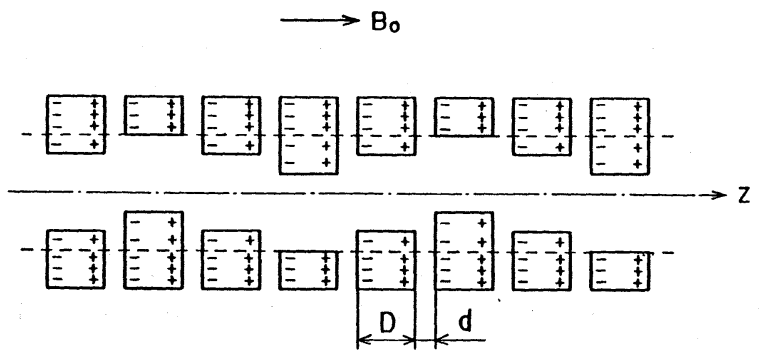

図 5．隙間のある強磁性体円筒の断面 
間 d をあけて並べる。乙れは極端に言えば隙間の所に現われる磁荷だけでヘリカル磁場を形成する方 法である。との方法により得られる回転変換角とシャ一長の計算值を図 6 亿示す。図 7 は $\mathrm{z}$ 軸に垂直 な平面に投影した磁力線の軌跡である。計算方法は前節で述べた様に，リング毎の磁位を計算して和 をとる方法を用いた。とてでは $\mathrm{r}_{\mathrm{L}}=4.8 \mathrm{~cm}, \mathrm{r}_{0}=4.1 \mathrm{~cm}, \varepsilon=0.1, \mathrm{D}=2.44 \mathrm{~cm}$ の鉄リン グを 15 度づつ回転させながら, $0.6 \mathrm{~cm}$ づつ離して並べた場合を考え, $\mathrm{B}_{0}=2 \mathrm{kG}, \mu_{0} \mathrm{M}=15 \mathrm{kG}$ とした。この結果, 回転変換角, シャ一長, 磁力線の軌跡は $\ell=3$ のヘリカル磁場の特徴を持ってい るととがわかる。

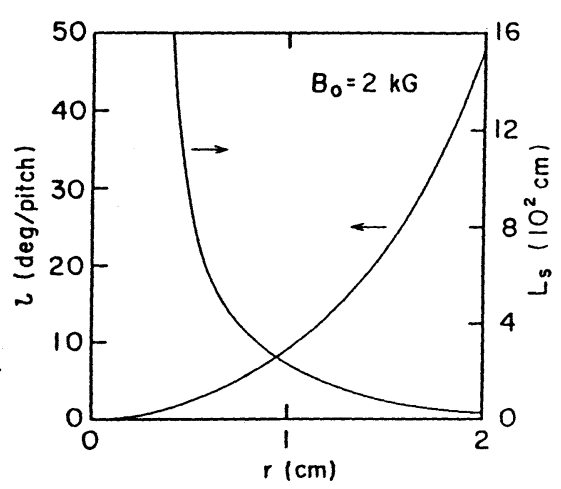

図 6. 回転変換角とシャー長

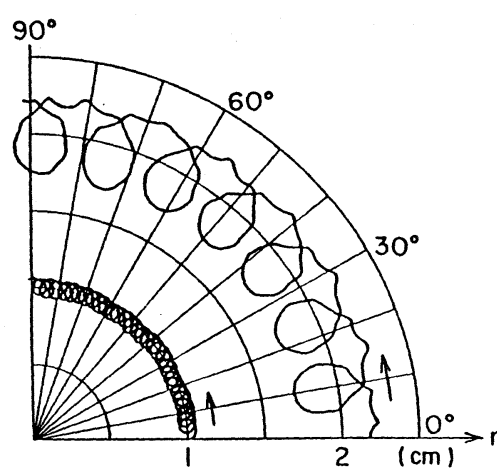

図 7. 磁力線の軌跡

\section{1-1-4 磁化ベクトルの計算方法}

1-1-2 節, 1-1-3 節で述べたつの方法には問題が二つある。一つは ( $1-3)$ 式で示し た仮定 $\mathbf{M}=\mathbf{M}(0 ， 0 ， 1)$ がどの程度成り立つかである。乙れは（1-7）式から予想されるとと であるが， $\mathrm{z}$ 軸に垂直な平面において磁荷の作る強磁性体内の磁界の強さ $\mathrm{H}_{\mathrm{z}}^{\prime}$ の向きが $\theta$ 方向に対し て正弦的に変わるため, 印加磁場と同方向となる部分が生じるととである。強磁性体内では $\mathrm{H}_{\mathrm{z}}^{\prime}$ は印 加磁場と逆方向に生じなければならないので, ( $1-3$ ) 式で無視した項についても考えなければな らない。

もう一つは強磁性体の減磁効果である。強磁性体の表面に磁荷が現われると減磁効果により $\mu_{0} \mathrm{M}$ の值は変化する ${ }^{8)}$ 。

$$
\mu_{0} \mathrm{M}=\frac{\mu_{0} x_{\mathrm{m}}}{1+\nu x_{\mathrm{m}}} \quad \mathrm{H}_{0}
$$


こてで $x_{\mathrm{m}}$ は磁化率, $\mathrm{H}_{0}$ は外部磁界の強さ, $\nu$ は減磁係数を示す。減磁係数 方向に磁化する場合は $=0$ となり $\mu_{0} \mathrm{M}$ は大きな值となるが, 薄い平板を厚さ方向に磁化した場合

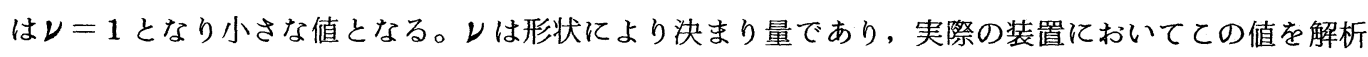
的に求めるてとはできない。

ここでは次の三つの場合を考え, 各々の計算值と測定值の比較を行なった。

○ case A…….. 各鉄リングが( $1-3)$ 式で表わされる様に一様に磁化している。

○ c a se B……印加磁場に垂直な面は一椂に磁化しているが, 平行な面に印加磁場と垂直な 成分を持った磁化べクトルが現われ，その大きさが，

$$
\mu_{0} \mathrm{M}_{\perp}=\mu_{0} \mathrm{M}_{\perp \max } \times \mathrm{g}(\theta) \quad(1-15)
$$

で表わされるとする。但し, $\mathrm{g}(\theta)$ は方位角方向 $\theta$ のみの関数であり,

$$
|\mathrm{g}(\theta)| \leqq 1 \text { とする。 }
$$

○ case C……… c a a e B の計算は非常に煩雑なため, $\mu_{0} M_{\perp}$ の効果を, 垂直な面の $\mu_{0} M$ の 值を一様に減じるとと置き換える。

これにより計算は簡便になる。

具体的な case Cの計算方法は，鉄リングの三角形の穴が回転する領域 $I\left(r \leqq r_{0}(1+\varepsilon)\right)$ と, その外側の領域 II $\left(r>r_{0}(1+\varepsilon)\right)$ とに分け（図8．case C参照), 各領域内では磁化べク トルの值は一定であるが，領域毎には異なった值を用いて計算する。各領域での計算方法は case A と同じ方法を用いる。

case Bでも実際の磁化分布とは一致しないが, こてでは比較的実際の分布に近いと考えられ る。図 8 に, 各々の場合の磁荷分布を示す。

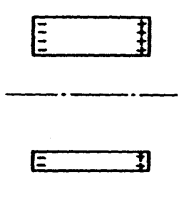

case A
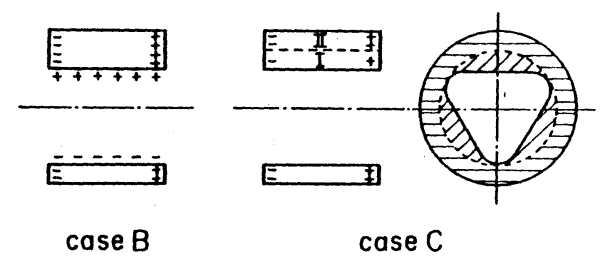

case C

図 8. 磁荷分布 
強磁性体壁によるへリカル磁場の形成とプラズマの安定化

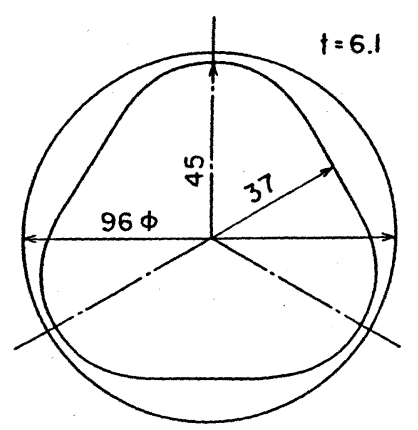

図 9.鉄リング

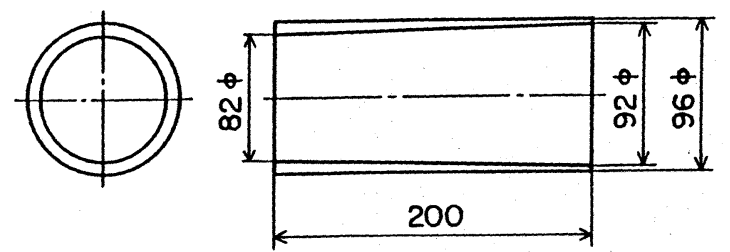

図10. 磁場補償リング

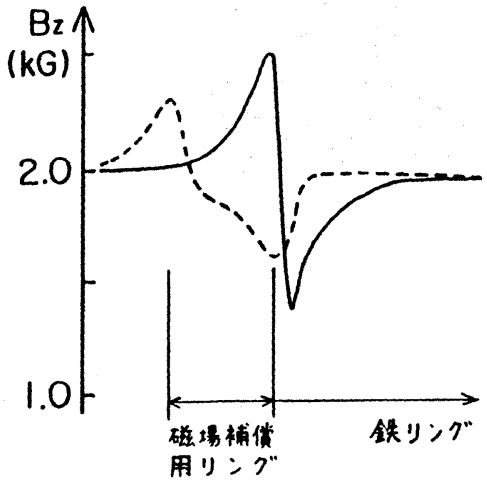

図11、実線：補償リングなし

破線 ：補償リングあり
1-2 実験装置及び実験方法

プラズマを囲むへリカル強磁性体壁は, 図9で示した鉄リングを並べるととにより 形成した。厚みのある鉄リングは, 図9の リングを数枚ねじらずに密着して重ね合わ せて形成した。

ここで問題となるのは, 装置が有限長であ るために，その両端面に現われる磁荷によ り磁場が大きく変形されるととである。乙 れを補償するために図 10 に示した様なり ングを, 装置の両端に設置した。これによ り，端面に現われる磁荷を傾斜のあるリン グの内壁に分散させ, 大量の磁荷が集中す るととを避けている。実際に測定した磁場 の值を図 11 亿示す。磁場の値は $\mathrm{z}$ 朝上で測 定したもので, 補償リングにより約 $40 \%$ 改善された。

図 12 亿実験装置の概略を示す。磁場は 装置の外側に設けられた電磁コイルにより 作られ, 真空容器内では一様であり, 1 $3 \mathrm{kG}$ まで変えるととができる。磁場の測

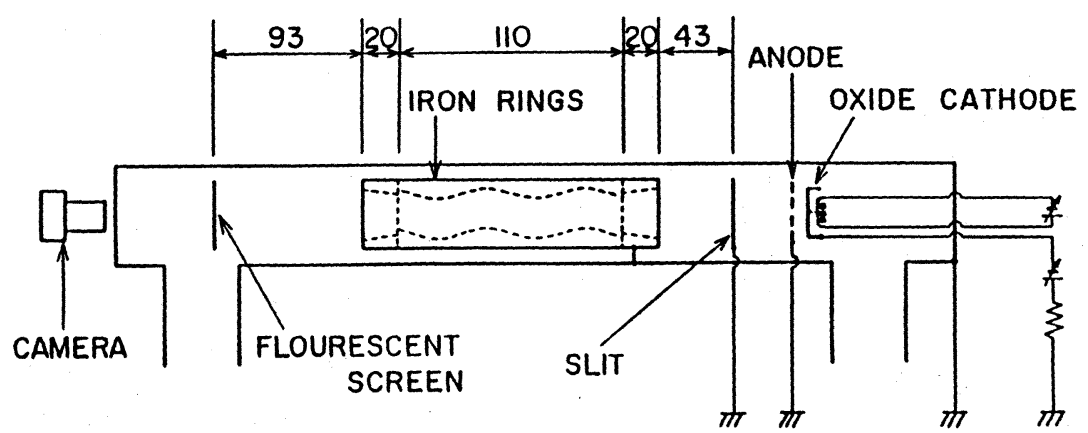

図12. 実験装置概略図 


\section{西村, 小森, 小出, 佐藤}

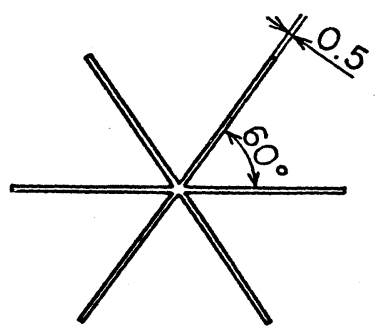

図13.スリットの形状
定はホール素子を用いて行ない, 主に $\mathrm{z}$ 軸方向と $\theta$ 方向の 磁場の変化を測定した。

また, 酸化物陰極を用いて電子ビームを作り, 図 13 に 示しを様なスリットを用いて変形して強磁性体円筒の一端 から入射した。他端には蛍光板が設置されており，との板 上に現われる輝跡を観測するととにより，回転変換角及び シャ一長を求めた。図14亿その輝跡を示す。

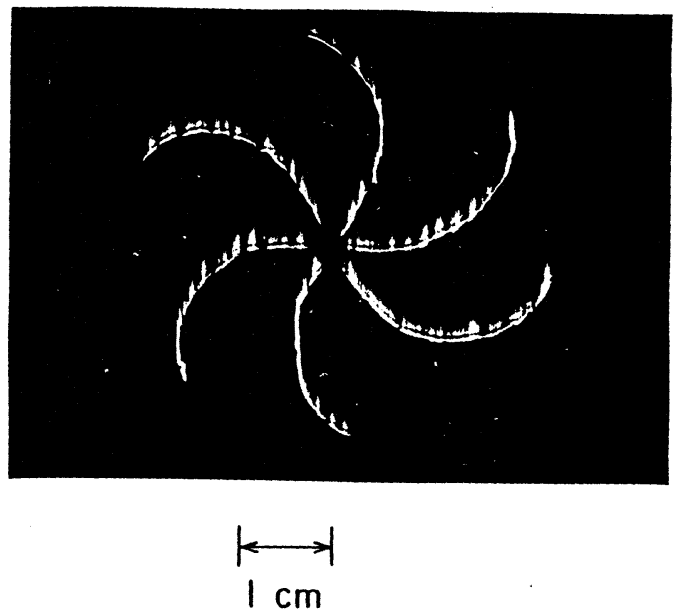

図14. 電子ビームの軌跡

\section{1-3 実験結果及び検討}

1-3-1 隙間のある強磁性体円筒によるへリカル磁場

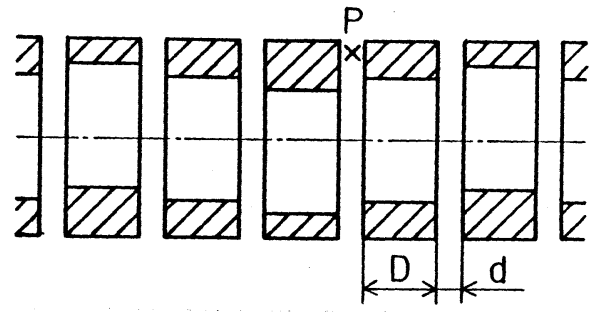

図15. 装置概 略 図
まず, 装置としての工作が簡単である。厚み のあるリングを隙間をあけて並べを場合につい ての実験を行なった。

装置は厚さDのリングを $\theta_{0}$ 度づつ回転させ ながら隙間 dをあけて並べた（図15）。

リングの個数は, 円筒長が約 $120 \mathrm{~cm}$ となる 様に決めた。 $\mathrm{d}=0.6 \mathrm{~cm}$ は常に一定とした。 


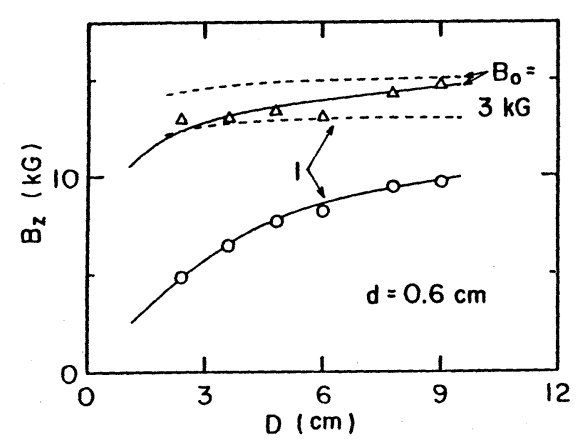

図16. $\mathrm{B}_{z}$ のリング長依存性 破線は計算値

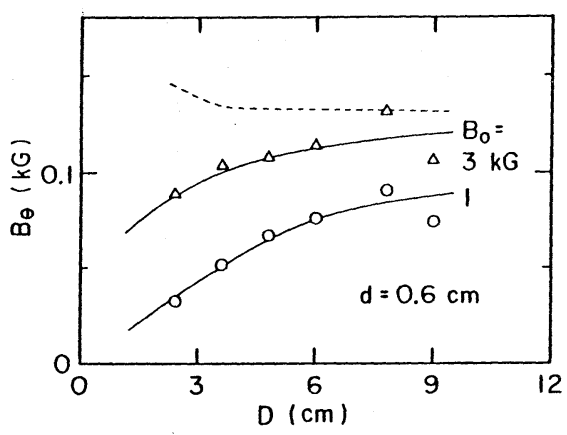

図17. $B_{\theta}$ のリング長依存性 $(r=2 \mathrm{~cm})$ 破線は計算値

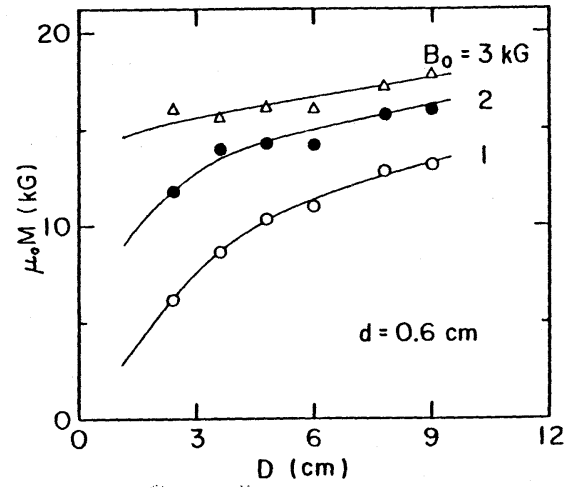

図18. 磁化べクトルの大きさ
四 16 に印加磁場方向の磁場 $\mathrm{B}_{\mathrm{z}}$ の測定 値と計算値を示す。測定は $\mathrm{B}_{\mathrm{z}}$ の半径方向 分布が最大值を示す点 $P$ （図15）で行な った。計算は, $1-1-2$ で述べた case $A$ そいて $\mu_{0} \mathrm{M}=18.2 \mathrm{kG}$ として 行なった。眓 17 は $\mathrm{r}=2 \mathrm{~cm}$ におけるポ ロイダル磁場 $\mathrm{B} \theta$ である。困 16 , 図17 亿 おいて計算値と測定値を比較するととによ り実際の $\mu_{0} \mathrm{M}$ の值を計算するととができ る。乙の結果を図 18 亿示す。Dが小さい, 即ちリンダが薄い領域では $\mu_{0} M$ は小さな 值となり $\mathrm{B}_{0}$ に比例している。てれは薄い 平板の磁化に近い状態であると考えられる。 ( 1 -9) 式からわかる様に, との領域 $(\mathrm{r}<4.5 \mathrm{~cm})$ では $\mathrm{B}_{0} と \mu_{0} \mathrm{M}$ が比例 しているために印加磁場 $\mathrm{B}_{0}$ を変化させて も回転変換角を変化させるととはでさない。 また $\mu_{0} \mathrm{M}$ 小゙さな值であるので大きな回 転変換角を得るととができない。従って以 下の実験では $\mathrm{d}=0.6 \mathrm{~cm}, \mathrm{D}=4.88 \mathrm{~cm}$ とした。

図 19 , 図 20 は $\mathrm{B}_{\mathrm{z}}$ 及び $\mathrm{B}_{\theta}$ の半径方向 分布である。乙とでは $\theta_{0}=15$ 度とした。 計算はcase Aについて行ったもので, 図 18 より $\mu_{0} \mathrm{M}=16.1 \mathrm{kG}$ とし。測定值 と計算值は比較的よく一致するが, $\mathrm{B}_{\boldsymbol{\theta}}$ の 值に $30 \%$ 程度の差がある。乙れは強磁性 体の一部が印加磁場と異なった方向に磁化 されたためと, 強磁性体の減磁効果による 


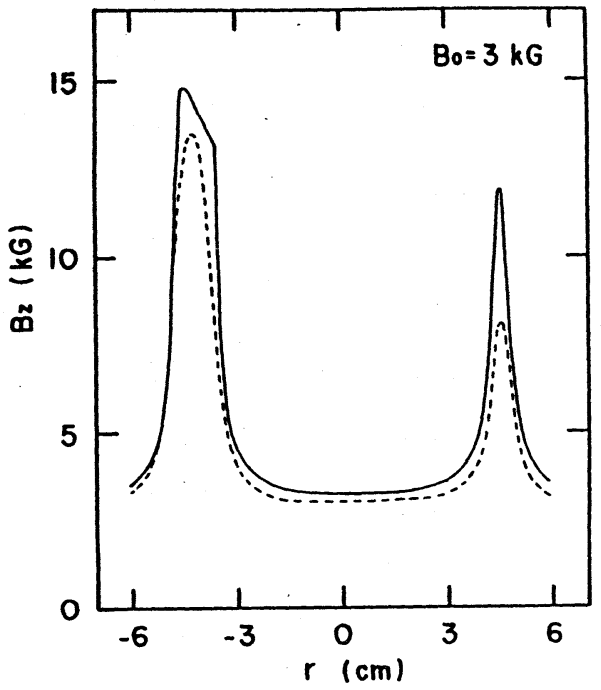

図19. $B_{z}$ の半径方向分布

実線：測定値

破線：計算值

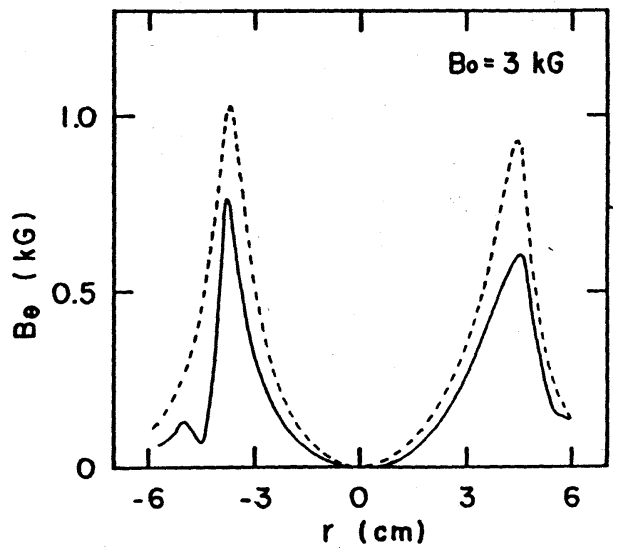

図20. $B_{\theta}$ の半径方向分布

実線：測定値

破線：計算值

ものと考えられる。従ってcase B, case Cについても考える必要がある。

図21, 図22にその結果を示す。破線で示したb)はcase B そついての計算結果である。 $\mu_{0} \mathrm{M}=16.1 \mathrm{kG}, \mu_{0} \mathrm{M}_{\perp \max }=0.124 \mathrm{kG}$ とした。一点鎖線で示した c)はcase Cについての計 算結果で, 領域 Iでは $\mu_{0} \mathrm{M}=9 \mathrm{kG}$, 領域 II では $\mu_{0} \mathrm{M}=16.1 \mathrm{kG}$ とした。 b)，c）を比較す

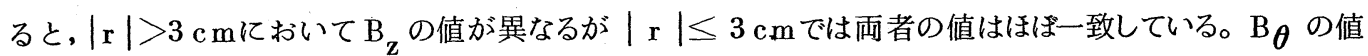
は測定した領域内では両者はぼ一致している。実際にプラズマの閉じ込めに用いる場合, 壁のでく近 傍までは用いないので, 磁場配位の計算は case C について行なえば十分であると考えられる。よっ て以下の計算値は, 特に表示がない限りは case Cについて計算したものである。

図 23 , 図 24 は, $\mathrm{B}_{\theta}$ 及び回転変換角 $\iota_{\mathrm{d}}$ の回転角 $\theta_{0}$ に対する依存性である。但し $\iota_{\mathrm{d}}$ は円筒長 当りの回転変換角であり, 円筒長は約 $120 \mathrm{~cm}$ である。また， $\mathrm{k}$ はヘリカルの波数であり $\theta_{0}$ とは

$$
k \times\left\{\frac{360}{\theta_{0}} \times(D+d)\right\}=6 \pi
$$

の関係が成り立つ。実線は計算值である。領域 I での $\mu_{0} M$ の值は図 17 から求めた值を用いた。 
強磁性体壁によるへリカル磁場の形成とプラズマの安定化

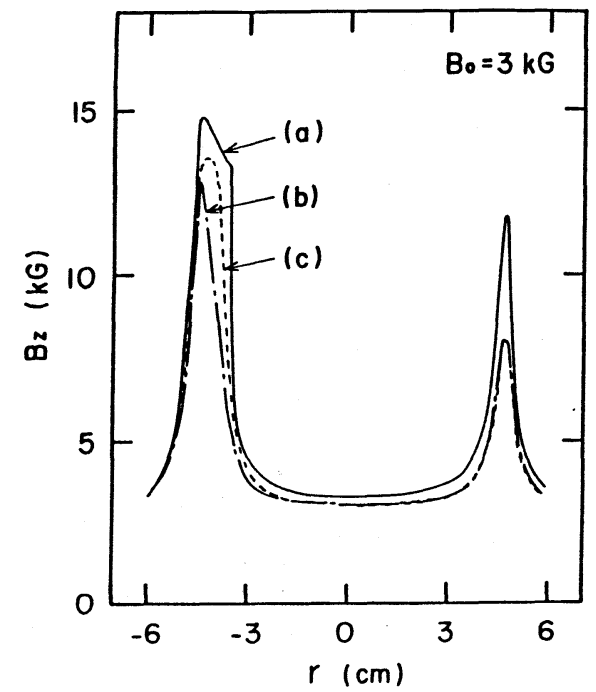

図21. $B_{z}$ の半径方向分布

a : 測 定 值

b.c：計算値

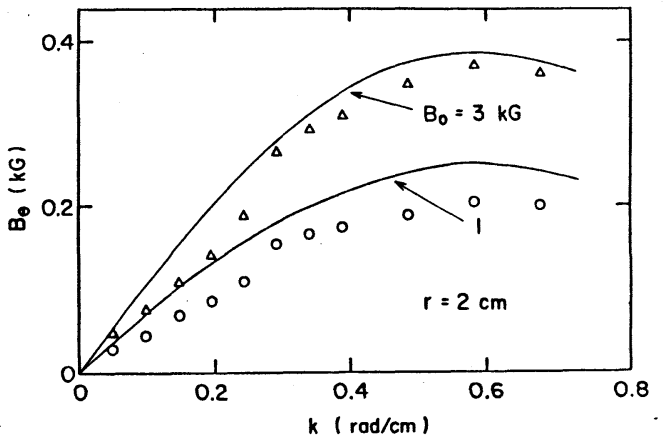

図23. $\mathrm{B}_{\theta}$ の回転角依存性

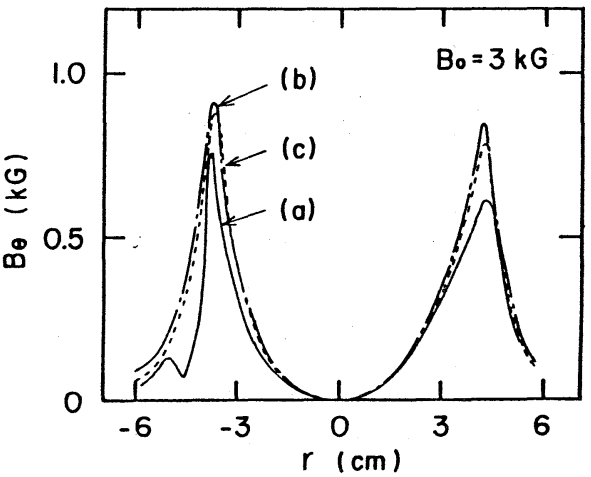

図22. $B_{z}$ の半径方向分布

a : 測定値

b.c ：計算値

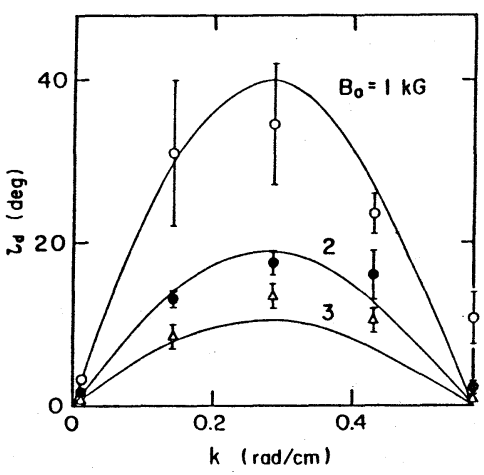

図24. $\iota_{d}$ の回転角依存性

$(r=2 \mathrm{~cm})$

領域 II での $\mu_{0} \mathrm{M}$ の值は, 領域 I の值の 0.56 倍の值を用いた。眓 24 から, ‘ $\mathrm{d}$ が最大となる $\theta_{0}=30$ 度を選び, との時の $c_{\mathrm{d}}$ とシャ一長 $\mathrm{L}_{\mathrm{s}}$ の半径方向分布を求めた。ての結果を図 25 , 図 26 亿示す。央 線は計算值である。

以上の結果, $\iota_{\mathrm{d}}$ は $\mathrm{r}=0$ の近傍で小さく, $\mathrm{r}$ が大きくなるに従って大きくなり, 逆に $\mathrm{L}_{\mathrm{s}}$ は $\mathrm{r}$ が大 きくなるに従って小さくなる等, $\ell=3$ のヘリカル磁場の特徵を示しているととがわかる。また, 計算値 と測定値はよく一致している。 
西村, 小森, 小出, 佐藤

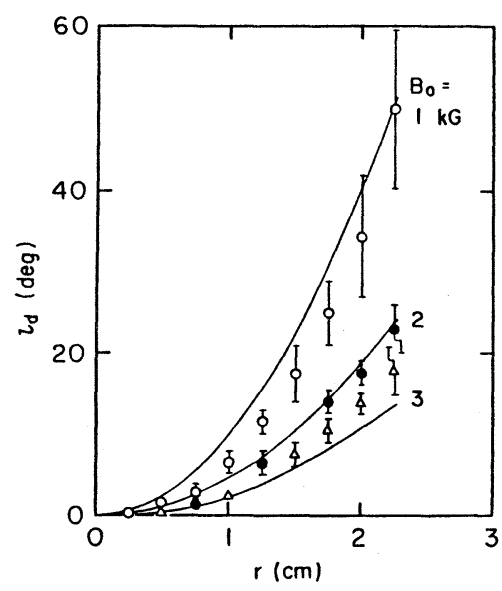

図25. $\iota_{d}$ の半径方向分布

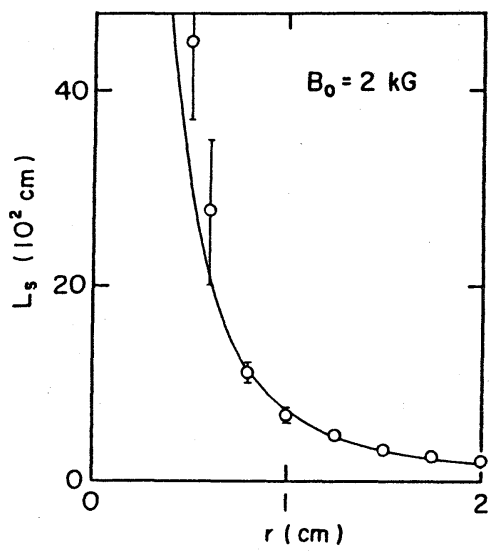

図26. $L_{s}$ の半径方向分布

\section{1-3-2．不連続に変化する強磁性体壁によるへリカル磁場}

こてでは図 9 に示した鉄リングを, 1 枚づつ回転させながら密着して並べた場合について述べる。 鉄リング間の回転角 $\theta_{0}$ とヘリカルの波数 $\mathrm{k}$ との間には

$$
\mathrm{k} \times\left(\frac{360}{\theta_{0}} \times \mathrm{t}\right)=6 \pi
$$

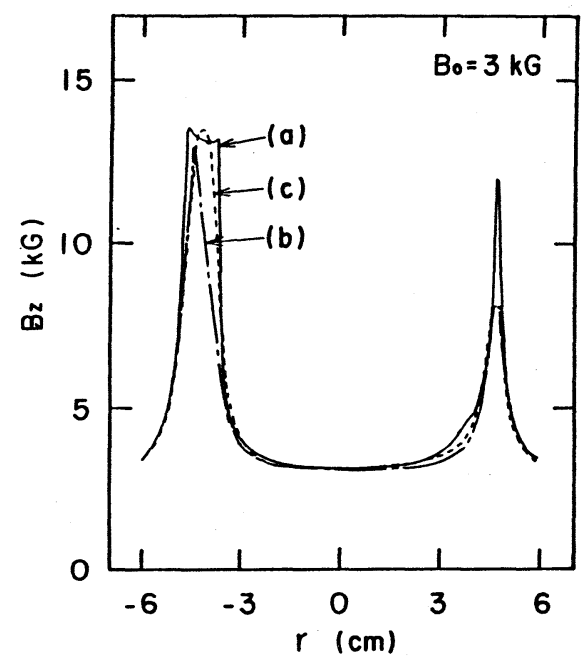

図27. $B_{z}$ の半径方向分布

$$
\text { a : 測定值 }
$$

$(1-16)$

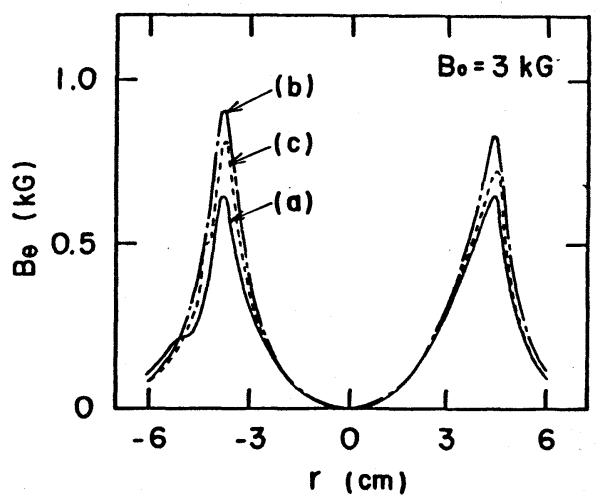

図28. $B_{\theta}$ の半径方向分布

$$
\text { a : 測定値 }
$$




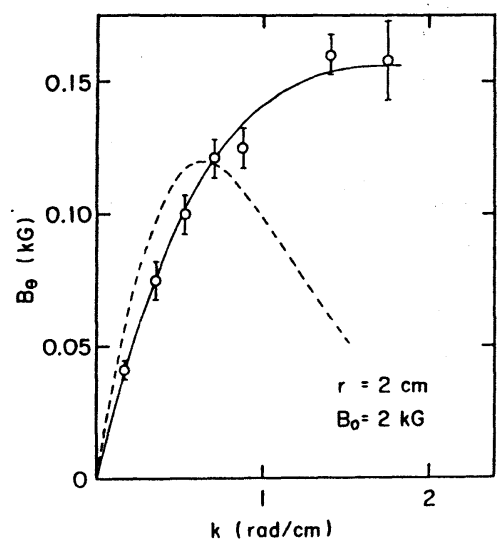

図29. $\mathrm{B}_{\theta}$ の回転角依存性

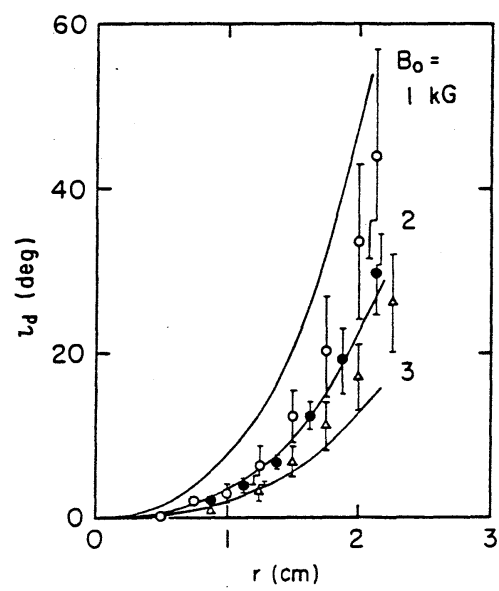

図30. $\iota_{d}$ の半径方向 分布

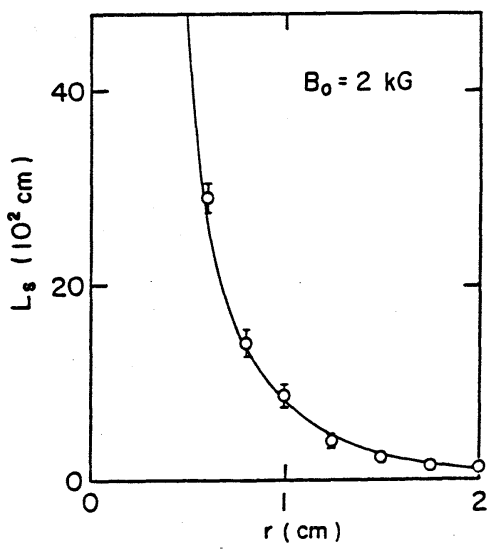

図31. $L_{s}$ の半径方向分布
が, 成り立つ。鉄リングは，磁場の半径方向分布の測定 のために中央に $6 \mathrm{~mm}$ の隙間を設けた以外は，すべて 密着して並べた。

図27,図28は $\theta_{0}=8$ 度 $(\mathrm{k}=0.69 \mathrm{rad} / \mathrm{cm})$ の場合の $\mathrm{B}_{\mathrm{z}}, \mathrm{B}_{\theta}$ の半径方向分布である。破線で示 したb)はcase Bについての計算值で, $\mu_{0} \mathrm{M}=16.1$ $\mathrm{kG}, \mu_{0} \mathrm{M}_{\perp \max }=0.302 \mathrm{kG}$ の值を用いた。一点鎖 線で示したc）はcase C についての計算值である。 領域 I で $\mu_{0} \mathrm{M}=7 \mathrm{kG}$, 領域 II とした。との結果, 前節同様プラズマの閉じ込めに壁 の近傍まで利用しないならば, 磁場配位の計算は case Cについて行なえば十分であると言える。

汹 29 は $B_{\theta}$ の回転角依存性を示す。破線は計算值 である。 $\mathrm{k}>0.8$ では測定值と計算值が一致しないが, これは鉄リング間の回転角が大きいため $\left(\theta_{0}>10\right.$ 度 $)$ 磁荷の分布が理想的な場合から大きくずれてしまって いるためと考えられる。

困 30 , 困 31 は $\theta_{0}=8$ 度の場合の $c_{\mathrm{d}}$ と $\mathrm{L}_{\mathrm{s}}$ の半 径方向分布である。実線は計算值である。前節同様, $\ell=3$ のヘリカル磁場の特徴を示しているととがわか る。前節の結果と比較すると, $\mathbf{r}=0$ の近傍では $C_{\mathrm{d}}$ は小さいが $\mathbf{r}$ が大きくなるに従って大きくなる。てれ は, 本節の方法のほうが， $\mathrm{r}$ が大きくなるに従ってシ ヤ一長 $L_{s}$ を短くできるてとを示している。実際, $\mathrm{r}=2 \mathrm{~cm}$ におけるシャ一長は約 $1 \mathrm{~m}$ と, 前節の方法 で得られる值の半分になっていることがわかる。

困 32 は $\Psi=$ 一定面である。破線は計算值を, 実線 は測定值をそれぞれ示している。測定は鉄リングの端 面から $5 \mathrm{~cm}$ 内側に， $\Psi=$ 一定面に近い形状のスリット 


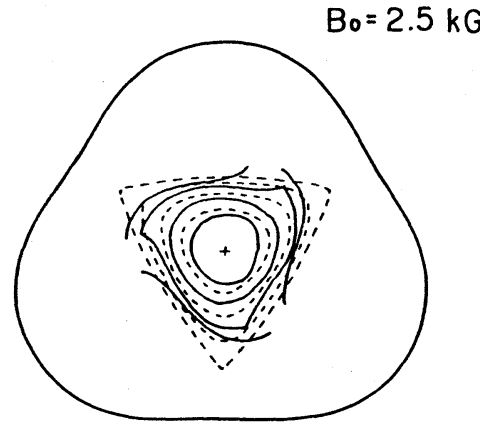

図32. $\Psi=$ 一定面

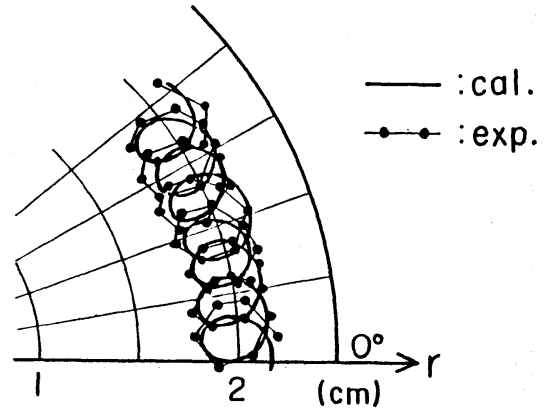

図33. 磁力線の軌跡

を設置して電子ビームを入射し，スリットから $1 \mathrm{~m}$ 位置に設置した蛍光板上の電子ビームの輝跡を 写真撮影して行なった。半径の大きい領域では計算で求めた面とズレを生じているが，てれは入射し たビームが正確に同一の $\Psi=$ 一定面上になかったために生じたものと考えられる。

図 33 は電子ビームを一点から鉄リングに入射し, 蛍光板を鉄リング内で移動させるととにより磁力線の軌跡 を求めをものである。図中の・がその測定点を示している。磁力線は $\ell=3$ のヘリカル磁場と同じ振舞をしている。

$1-3-3$ 検 討

1-3-1 節で述べを隙間のある強磁性体円筒を用いる方法では, 厚いリングを用いるために工作 及び組み立てが容易となる。また，隙間をあけて並べるために大きな $\mu_{0} \mathrm{M}$ の值を得るてとができる。 しかし, 単位長当りのリングの個数が少ないため, 1-3-2節と同程度の回転変換しか得られない。 また, 図7で示した様に磁力線は滑らかな軌跡を描かないという欠点がある。てれに対して, 1-3-2 節で述べた方法では薄い鉄リングを用いるために工作及び組み立てはめんどうであるが，磁力線は滑 らかな軌跡を描く。さらにての方法の有利な点は, シャ一長を短くできるてとである。

磁場配位の計算は, 厚いリングを用いる場合も, 薄いリングを用いる場合も鉄リングを二つの領域 に分けて, 内側の領域の $\mu_{0} \mathrm{M}$ 值を小さくするてとにより比較的簡単に計算するてとができ，その 結果は測定值とよく一致した。

以上の結果, 回転変換が必要で短いシャ一長は特に必要でなく，また多少のエラー磁場が問題とな らない場合には，工作や組み立てが簡単な厚い鉄リングを用いた方が便利である。しかし，エラー磁 場をできるだけ小さくしたい場合や，短いシャ一長が必要な場合は，薄い鉄リングを密着して並べな ければならない。 


\section{§ 2. シャーによる不安定波の安定化}

\section{2-1 実験装置及び実験方法}

実験に用いたプラズマは, 約 $2000^{\circ} \mathrm{K}$ 熱せられたタングステン板(ホットプレート)にカリウム

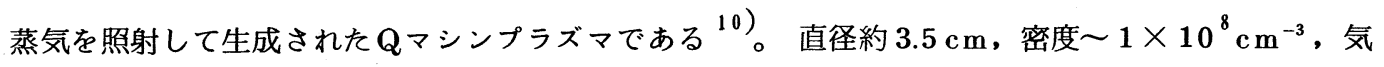
圧 $\leq 3 \times 10^{-6}$ Torr であり，鉄リング内に設置された終端板（ターゲット）により終端されている。 ホットプレート, 真空容器及び鉄リングは接地され零電位に保たれている。ターゲットは鉄リングと 絶縁されており, バィアス電圧をかけられる様になっている。

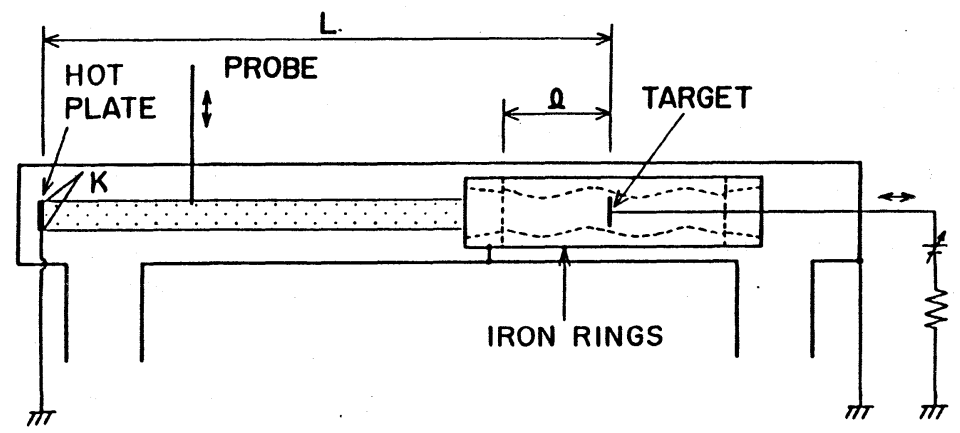

図34. 実験装置概 略図

鉄リングは, シャ一長をできるだけ短くするために, 薄い鉄りングを密着して並べた。 $\theta_{0}=8$ 度 $(\mathrm{k}=0.69 \mathrm{rad} / \mathrm{cm})$, 全長約 $150 \mathrm{~cm}$ とした。乙の鉄リングとターゲットは各々独立に移動可能 で, プラズマ柱長 L及びプラズマ柱にかかる鉄リング長 $l$ を変えるてとができる。図 34 に装置の概 略図を示す。

プラズマの諸パラメータは半径方向に移動可能なエミッシブ・プローブを用いて測定した。

\section{$2-2$ 実験結果及び検討}

プラズマに電流を流すととにより, 図35にスペクトル図を示した様な波が励起された。とてで $\mathrm{u}_{\mathrm{d}}$ は電子の流速を示している。ターゲットに正の電圧を印加した場合, ターゲットに流入する電流は主 に電子電流で, その值は

$$
\mathbf{I}_{\mathbf{T}}=\mathrm{Senu}_{\mathbf{d}}
$$

で表わされる。とてで $\mathrm{S}$ はターゲットの面積, $\mathrm{n}$ はプラズマの平均密度である。図中の $\mathrm{v}_{\mathrm{e}}$ は電子の 


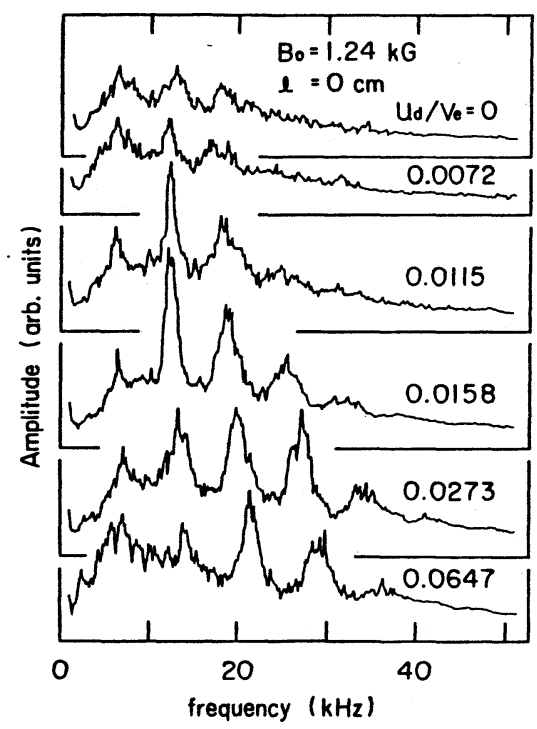

図35. スペクトル図

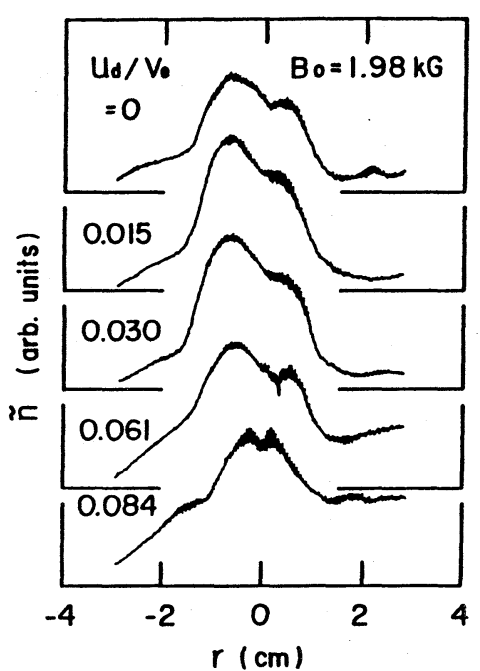

図36. 密度摇動の半径方向分布

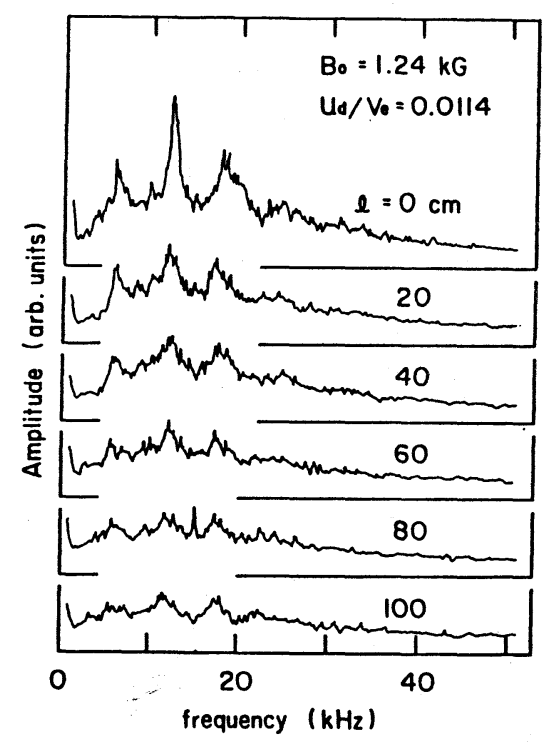

図37. スペクトル図
熱速度を示している。流速 $\mathbf{u}_{\mathbf{d}}$ を大きくしていくと $\mathrm{m}=2$ のモードの波が励起され, さらに流速を増すと $\mathrm{m}=2$ のモードの波は減衰して, より高次モードの波 が励起されていく。との波は密度勾配のきつい位置に 立っており, 密度摇動と浮遊電位摇動の位相差が約 60 度であるとと等から，ドリフト波であると考えられる ${ }^{11 ） 。 ~}$ 図 36 は密度摇動の半径方向分布である。

このドリフト波を, 鉄リングを用いて形成されたシ

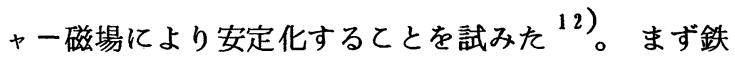
リングを固定して, ターゲットのみを移動させて実験 を行なった。困 37 にそのスペクトル図を示す。プラ ズマ柱にかかるリング長 $l$ が長くなるに従って波が安 定化されているのがわかる。しかし,ターゲットの移 動によりプラズマ柱長Lも変わってしまっている。 そこでシャーによる安定化の効果をより明らかにする ためにターゲットを固定してプラズマ柱長Lを一定に 


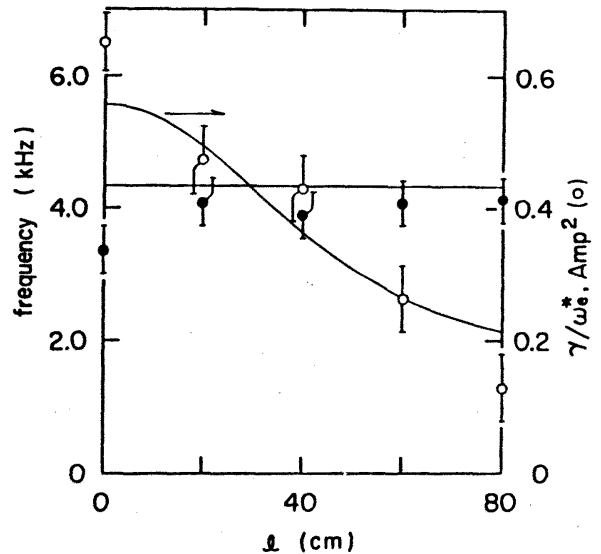

図38、鉄リング長依存性 $u_{d} / v_{e}=0.0294$

保ち、鉄リングのみを移動させるととにより $l$ を変化させた。ての結果を図 38 に示す。 とは波の成長率を, Amp は測定した波の振 幅を示している。こてでは, 定常状態に達し た時の波の振幅の 2 乗と成長率との間には

$$
r \propto|\operatorname{Amp}|^{2} \quad(2-2)
$$

の関係があるととに着目して ${ }^{13)}$, 比較を行な った。鉄リング長 $l$ が大きくなるに従って波 が減衰しているのがわかる。従って鉄リング により作られたシャーにより, 波が安定化さ れたと考えることができる。

\section{総 括}

ヘリカル強磁性体壁により $\ell=3$ のヘリカル磁場を実験的に形成するてとができた。ての樣な複雑 な磁場配位を強磁性体を用いるととにより実現したのは本研究が初めてである。作られた磁場配位が $\ell=3$ のヘリカル磁場であるととは, 磁場の空間依存性等が $\ell=3$ のヘリカル電流により作られる磁 場配位の特徵と一致しているととにより確認された。磁場の計算は, 装置長が無限で骬らかな内壁を 持ち, 磁化はすべて円筒軸方向に一様であるという理想的なへリカル強磁性体を仮定した生田らの式 をそのまま用いることはできないが, 強磁性体の減磁効果等を $\mu_{0} \mathrm{M}$ の值を小さくするてとで置き換 えるととにより, 比較的容易に計算するととができ, その結果は強磁性材料に固有な飽和磁化の 0.5 〜 0.7 倍の值を用いると実験結果とよく一致した。本装置で得られたシャ一長は $\mathbf{r}=2 \mathrm{~cm}$ において約 $1 \mathrm{~m}$ と短く, プラズマに電流を流すととにより励起されたドリフト波を安定化するてとができた。 本研究で用いた強磁性材料は軟鉄であり, 飽和磁化の值は $\mu_{0} \mathrm{M} \cong 15 \mathrm{kG}$ ではぼ定であるので, 印加磁場が大きくなる程, 強磁性体の有効性は薄くなる。しかし, 数 $\mathrm{k} G$ 程度の 比較的小さい印加磁場 での実験には十分有効であり, 既存のステラレータ装置にほぼ匹敵する回転変換角を実現するととが 可能であると考えられる。また, Permendur の様に, 飽和磁化の值が $\mu_{0} \mathrm{M}=24.5 \mathrm{kG}$ と大 きな值の材料を用いれば，さらに大きな閉じ込め磁場の装置に対しても有効に利用できると考えられ る。 
西村, 小森. 小出, 佐藤

生田らの計算によれば ${ }^{1 ）}$, 鉄を用いることにより, 小半径 $5 \mathrm{~m}$, 大半径 $25 \mathrm{~m}$, 閉じ込め磁場 3 テ スラ, 回転変換角し/ $2 \pi \cong 0.5$ 程度の核融合炬が実現できると結論されているが, 我々の研究によ ると，実際に鉄を用いて実現するてとは難しい。しかし，上述のPermendurの様に飽和磁化の值の 大きな材料を用いるととにより実現できる可能性があると考えられる。

謝 辞

本研究の進行上, 常に有意義な助言と討論を行なって下さいました佐伯紘一氏並びに, 甶山力三氏 に深く感謝致します。また，実験装置の製作及び維持に関して，すぐれたアイデアと技術を提供して 下さいました石田裕康氏に深く感謝致します。

最後に, 実験を手伝って頂いた関雅彦氏並びに，研究室の皆様に感謝致します。

参考文献

1) G. Sheffield, Princeton Univ. Plasma Phys. Lab. MATT-721 (1969).

2) 浜崎 他, 日本物理学会春の分科会予稿集 4 (1977) 6pS1, p108；N. Sato, in Proc. of International Conference on Plasma Physics, Nagoya, Japan Vol.2 (1980) 138 ;

A. Komori et al., Phys. Lett. 78 (1980) 143.

3) K. Ikuta and K. Hirano, Nucl. Fusion 20 (1980) 35 ; K. Ikuta, Nagoya Univ. Institute of Plasma Phys. IPPJ-451 (1980) ; K. Ikuta, Nagoya Univ. Institute of Plasma Phys. IPPJ-458 (1980).

4) L. Spitzer, Phys. Fluids 1 (1958) 253.

5) 宇尾, 核融合研究 1 (1958) 20, 2 (1959) 247, 3 (1959) 679; K. Uo, J. Phys. Soc. Japan 16 (1961) 1380.

6) C. Gourdon et al., Plasma Phys. and Contr. Nucl. Fusion Research (Proc. Conf. Novosibirsk, 1968) 1, IAEA, Vienna (1969) 847.

7) G. N. Watson, A TREATISE ON THE THEORY OF BESSEL FUNCTIONS (CAMBRIDGE UNIV. PRESS, LONDON, 1922).

8）宮本 健郎，核融合のためのプラズマ物理（岩波書店，東京，1976）。

9) 竹山 説三, 電磁気学現象理論（丸善, 東京, 1969). 
10) R. W. Motley, Q Machines (Academic, New York, 1975) ; 佐藤 徳芳, 電気四学会東海 支部連合大会 (1973) $177 ;$ N. Sato et al., Phys. Rev. Lett. 34 (1975) 931.

11）抵抗性ドリフト波について：

H. W. Hendel et al., Phys. Rev. Lett. 18 (1967) 439 ;

H. W. Hendel et al., Phys. Fluids 11 (1968) 2426 ; L. G. Schlitt and H. W. Hendel, Phys. Fluids 15 (1972) 1578 ; R. F. Ellis and P. E. Motley, Phys. Fluids 17 (1974) 582.

無衝突ドリフト波について :

P. F. Little and C. R. Middleton, Nucl. Fusion 9 (1969) 67 ;

P. Brossier et al., Phys. Rev. Lett. 26 (1971) 124 ;

R. Hatakeyama et al., Phys. Lett. 74 (1979) 215.

12) シャ一磁場中の抵抗性ドリフト波について：

F. F. Chen and D. Mosher, Phys. Rev. Lett. 18 (1967) 639 ;

H. D. Pacher et al., Phys. Rev. Lett. 25 (1970) 1559 ; Y. Nishida et al., Phys. Fluids 15 (1972) 1859 ; V. S. Voitsenya et al., Sov. J. Plasma Phys. 5 (1979) 298 .

13) シャー磁場中の無衝突ドリフト波について：

P. E. Stott et al., Phys. Rev. Lett. 25 (1970) 996.

14) L. D. Landau and E. M. Lifshitz, Fluid Mechanics (Pregamon, London, 1960). 